\title{
ANALYZING LOCAL FASHION COMMUNITIES/SME'S FROM ETHIOPIA AND UKRAINE AND DEVISING SOLUTIONS FOR SUSTAINABLE BUSINESSES
}

\author{
Karan Khurana*1 (iD \\ Kateryna Ryabchykova ${ }^{2}$
}

${ }^{1}$ EiTEX, Bahir Dar University, Ethiopia,

${ }^{2}$ Ukrainian Engineering and Pedagogical Academy, Ukraine

\begin{abstract}
The ever-increasing share of fast fashion consumerism shadowed the profound craftsmanship of local produce in the developing countries. This subsequently created hardship to the local communities and designers across the non-western world which belongs to small and medium scale enterprise sector. Beyond this the fashion commodities saw a substantial fall in design elements which made the products very banal in nature. Consequently, the trade turned towards conscious consumption and here emerged a few sustainable designers and craft-oriented communities which attracted attention in the recent past. Problems of sustainability and consumption are burning issues nowadays, fashion houses and international brands propagandize purchase for better consumer base, whereas originally sustainable local-based craftsmen still stay in the shade. Due to lack of expert management and target allocated branding real sources of national heritage cannot gain fame on the international level. In this research, we have studied and analyzed the problems faced by hereditary communities and ethnic designers which lie in small and medium scale enterprise sector from two developing economies Ethiopia and Ukraine. The main purpose of the work is to design effective marketing \& management strategy for expansion of local communities and entrepreneurs to the international level. Particular attention is given to communities and designers who promote national heritage and for a part of small and medium scale enterprises which are one of the concerns of economic development of the two countries.
\end{abstract}

Keywords: Fashion Communities, Small and Medium Scale Enterprise (SME), Fashion Marketing and Branding, Non-Western Economies, Sustainable Development.

JEL: P42, M31, Q01

To cite this document: Khurana, K., \& Ryabchykova, K., (2017). Analyzing Local Fashion Communities/SME'S from Ethiopia and Ukraine and Devising Solutions for Sustainable Businesses. JDE (Journal of Developing Economies), 2(2), 58-72.

\section{Introduction}

In the era of rapid technological and digital innovations all sectors of economy rebuild their business models towards more flexible and high-speed structures. Introduction of digital recourses gave possibility to move faster and create more textiles and retail sectors take advantage of introduces technologies in the different possible ways. Digitalized system of supply

JDE (Journal of Developing Economies) p-ISSN: 2541-1012; e-ISSN: 2528-2018

DOI: http://dx.doi.org/10.20473/jde.v2i2.6057

Open access under a Creative Commons Attribution 4.0 International

(CC-BY) 
chain management influenced precipitance of product manufacturing and expansion, what gave possibility to mass-giants supply world with their products in countable hours. Globalization of informative sources presented prevails of identical and monopoly trends all over the globe. Expansion of offshore companies and diversified business groups established monopolies even in the most emerging economies (Khanna \& Yafeh, 2007). Moreover, outspread of online-shopping and over globe shipping possibilities introduced new purchasing experience, where customers can contact direct source, without correspondence to local suppliers. It's, in turn, influenced customer choice making and dislocated balance between global and local business communities (Schoenbachler, 2002).

Enumerated factors influenced introduction of new retail monopolies, which happened to be residents of the most developed countries, such as USA and Western Europe. Conversely, developing economies or in other words "non-western communities" lost control even over their own local market. In addition to all economic consequences, those causes influenced degrading of national craftsmanship development and heritage oblivion. Similar problems appear over all developing countries; however as main research area was taking into consideration two main regions: Africa and Eastern Europe which are presented on example of Ethiopia and Ukraine accordingly. We identified that local fashion community belong to small and medium scale enterprises sector of these countries and hold a very important part in development of non-western economies.

While main problems, reasons and intended way of development were outlined in analyzed sources, proposed solutions still deliver superficial and fragmented implementation. This concurrent estimate subsisting contradiction between growing inequality of global versus local brands and imperfection of proposed universal marketing and management solutions. Above-mentioned demonstrates existence of problem which we can characterize as insufficient local strategy for marketing and management development within researching area.

\section{Literature Review}

In developing economies, Small Business Entrepreneurship plays a tremendous role in economic and social development of the country. These enterprises largely represent a stage in industrial transition from traditional to modern technology. There is a clear indication that these economies are moving very quickly towards mass production and joining the club of producing economies as this is one of the revenues making sector for economies. Small and medium-size enterprises are a very heterogeneous group which includes a wide variety of firms-village handicraft makers, small machine shops, restaurants, and computer software firms-that possess a wide range of sophistication and skills, and operate in very different markets and social environments. The statistical definition of SMEs varies by country and is usually based on the number of employees or the value of assets (Hallberg, 2000).

Ethiopia's economy is primarily based on agriculture (46\% of GDP) but over the last 5 years the government has been determined to diversify the exports with a priority set for strategic sectors like light manufacturing, textile - and garment manufacturing. The Ethiopian textile - and apparel industry has grown an average of 51\% over the last 5-6 years and some 65 international textile investment projects have been licensed for foreign investors. Retailers like H\&M, Primark and Tesco have established offices in 2012 and are buying clothing- finished products- from Ethiopian manufacturers (van der Pols, 2015). The Small and Medium Enterprises informal and Small Manufacturing Enterprise sector (SMEs) contributed value added of Birr 8.3 million in 1996. Based on the 1992/93 data, this figure constitutes about $3.4 \%$ of the GDP, $33 \%$ of the industrial sector's contribution and $52 \%$ of the manufacturing sector's contri- 
bution to the GDP of the same year (Gebrehiwot, 2006). The five-year Growth and Transformation Plan (GTP) of Ethiopia envisages to create a total of three million micro and small scale enterprises at the end of the plan period (NBE, 2011). SMEs in Ethiopia comprise of those having paid up capital of 20,000-500,000 Birr (about US\$4,000-100,000) and more than 500,000 Birr, respectively; or having 11-15 employees and more than 50, respectively. However, as was mentioned by several authors, in many African countries, the local textile activities are either suffering or in near collapse despite NGOs and bi-lateral initiatives to bolster production and nurture the sector. Many textiles with alleged indigenous prints sold to Africans who use local dressmakers to create tunics and wraps (particularly in the west and south of the continent) are now manufactured in Asia and sometimes the prints are even designed in Europe (Dubois, 2008).

Ukrainian Economy is majorly represented by providing services (60\% of GDP), and in past resent years import dramatically privilege upon export (Central Intelligence Agency). Apparel sector is represented by roughly 6000 legal entities (including individual entrepreneurs), producing different types of textile wear, including fur and knitted goods (Tsepko, 2010).Ukraine is a case where the entrepreneurial talent by itself is not enough for fast evolution of small and medium-sized enterprises. The shadow economy in Ukraine has remained fairly stable over the years. It constitutes $60 \%$ of official GDP (Schoenbachler, 2002). Global companies as M\&S, Zara and alliance brands are presented in large Ukrainian cities, however cheap Chinese and Turkish goods is more affordable choice for citizens. Regarding local brands and national heritage, it was outlined that Ukrainian national crafts are facing rebirth and innovation and gaining fame on international level. However, main changes operate in luxury segment, while mass-production is still in delay.

\section{Importance of Local Communities to developing economies}

Industrial development and entrepreneurship are two side of a coin. Entrepreneurship encompasses the promoters, government and financial institutes. Entrepreneurship development is essential to solve the problem of economic development through creating local employment, balanced area development, decentralization of economic power and diversion of profits from rich to middle class \& poor. Many local innovations go unnoticed because of innovator's limitations in commercializing the product. If stakeholders of entrepreneurship work in tandem, SMEs can grow fast. For developing country, to promote SMEs is a winning strategy, which decentralize the wealth more equitably compared to the large industry. SMEs create local employment; direct \& indirect. SMEs can be feeder to the large industries. SMEs can be tool for exploiting local innovations and enhance consumer life conditions (Sapovadia, 2015). Benefits of SMEs can extend to the external sector, through their launching of new products. The role of the private sector, including SMEs, as engine of growth was illustrated by the postwar recovery in Austria and Germany and by the diverging paths of Central and East European and Baltic countries. Most governments also recognize the potential of SMEs to create employment and contribute to poverty eradication, although in many cases this potential is not being fulfilled (Reinecke and White, 2004). They constitute a large part of the economy in most countries, dominate the industrial and commercial infrastructure and have significant roles in economic growth (OECD, 2010; Tetteh and Burn, 1999; Curran and Blackburn, 2001). In addition Carrier (1994) said that the SMEs are more fertile than their larger counterparts in terms of innovation and development.

With the end of the central planning system, SMEs have become the major driving force for the development of the economy in many transition countries.In Africa, Okpara 
(2011) argued that SMEs play a momentous role in the macro economy. There has been an obvious rise in the widespread emergence of SMEs in Sub-Saharan Africa.The importance of the micro and small enterprises sector in Ethiopia, particularly for the low-income, poor and women groups, is evident from their relatively largepresence, share in employment and small capital requirement.Small and medium-size enterprises in Ukraine in 2000 gave work to $9.5 \%$ of employed people (6\% of working age population) and produced $8.6 \%$ of GDP of Ukraine (ICS, 2001). They are not only providing job opportunities, but also, acting as suppliers of goods and services to large organizations, and any lack of their product quality could adversely affect the competitive ability of the larger organizations (Rose et al., 2006; Greenan et al., 1997; Ghobadian and Gallear, 1996; Parkin and Parkin, 1996; Storey, 1994). These are sufficient reason for governments and other stakeholders in development to be interested in micro and small enterprises.

\section{A brief on Local Communities/SME'S in Ethiopia and Ukraine}

We researched on the four SME's/local communities which contribute to fashion and textile sector in both the countries.

\section{Awra Amba (http://www.visitawraamba.com/)}

"I wanted to live in a place where women and men live as equals and where all of our children can go to school. I didn't want religion and tradition to dictate every aspect of our lives. So I decided to create a place where everyone is respected equally, and works collectively, so we can stand a chance of coming out of poverty."- Zumra Nuru.

Awra Amba is an Ethiopian community of about 463 people, located 73 kilometers east of Bahir Darin the Debub Gondar Zone. It was founded in 1980 with the goal of solving socio-economic problems through helping one another in an environment of egalitarianism-in marked contrast to the traditional norms of Amhara society. Founded by Zumra Nuru, who currently serves as co-chairman of the community, with 19 other people who shared his vision, as of 2007 Awra Amba has some 400 members, and is lauded as a model to alleviate poverty and promote gender equality in a country where women are generally subservient to men. The village is unique not only for its attitudes toward gender, religion, and education, but for the social security it provides its members in need. Minna Salami (Nigerian-Finnish writer and commentator, and the founder of Ms Afropolitan) suggested that environmental sustainability is not a goal in Awra Amba, it is a reality. What is now a necessary but catchy concept, namely "the green economy", is not a new idea in Awra Amba. As they cannot live on farm activities, given the soil poverty and the scarcity, they have diversified into the weaving business, using both traditional and modern weaving machines. They started off by building one traditional weaving machine, which they used to make scarves, blankets and clothing to sell. Soon they had saved enough money to buy the parts for another machine. Their production capacity doubled and so their operation started to grow and grow. The cottage industry produces shirts, dresses, skirts, table clothes, scarfs, hats, towels, blankets and many other forms of garment using attractive design (Haile Michael, 2006). Begging is an activity frowned up on, the most appropriate way to contribute would be to buy some of the handspun cotton and wool items in the warehouse: - a range of "shamas", scarps, shirts and blankets costs half what can be paid in most other parts of the country. We came to know about the community from travelers and NGO's (non-governmental organizations) which specially traveled to see the lifestyle as preached by ZumraNuru and bought unique fashion and lifestyle products at a very affordable price. 
Today, Awra Amba is a thriving, gender-equal democracy and a hugely successful social enterprise. This has allowed the community to invest in social services, like education and healthcare, which they have shared with thousands of people in the region. These efforts have gone a long way in helping improve their relationship with many of their former enemies - most of whom now regard Awra Amba as a positive example of change and development.

\section{Mafi (http://mafimafi.com/)}

Mafi is a fashion designer based in Addis Ababa. She started her career at 16 as a model and musician, while simultaneously studying nursing. She left school and quit modeling to follow her passion and become a professional fashion designer. She has since gained critical acclaim for her cutting-edge designs; winning the 2012 Origin Africa's design award, showcasing her work at African Fashion Week, New York 2012, and winning the 2010 Designer of the Year award from Alliance Ethio-Française at European Fashion Day in Addis. Mafi works exclusively with hand-woven fabrics made by women. She creates clothing and accessories which are fresh and cutting-edge and at the same time very wearable. Working with hand-woven fabrics is a way for Mafi to give back and to support women weavers who are often marginalized within the male-dominated weaving community. The connection between hand-woven fabrics and Ethiopian culture and history is something Mafi explores in her work. Culture and tradition can sometimes become as essential and as invisible as air. Pushing herself creatively Mafi produces contemporary pieces with ancient fabrics, giving visibility to the diversity and depth of Ethiopian culture and tradition. Brand is known for its strong Ethiopian essence across the fashion centers of the world and is admired for contemporizing of design and culture in the form of garments. We consulted Mafi to systematize her company for better selling and also analyzing her problems. The company wanted to expand from specialized market to mass markets to basically increase in revenue. They also wanted to open a retail outlet for better market presence and reaching the consumer.

\section{Musthave (http://musthave.ua)}

Musthave is young retail brand started by two young girls in 2010 - Anya Kovalenko and Nastya Yancovenco who studied together in university and were never connected to fashion industry. They just had dream to create some business together. After some time, these entrepreneurs faced the problem of high cost for qualitative outfits. Foreign mass-markets are either expensive or have low quality, or some of them don't attract Ukrainian consumer by its models and designs. That is how these women decided to open their own mass-market brand, which will sell garment for affordable price and good quality. Now brand is becoming more and more popular among citizens of capital. MustHave has own production of 1,000 square meters, 6 stores in Ukraine, 200 employees, on-line shopping, and representation of brand in 10 countries. Fabrics and accessories designers buy in Europe (they explain it by low quality of Ukrainian textile), but all manufacturing process is settled in Kiev. With regards to international market, brand claims that consider it in their future plans. Perhaps now it's more a skeptical dream than plans. Designers explain that their first purpose is help to reinvent Ukrainian mass-market, and they want to proof that country can demonstrate quality outfits for affordable prices, but unfortunately now European consumers associate Ukrainian products with either high price or very poor quality. To break this stereotype, we first have to leave strong footprints in our market, believe designers, and just then build strategies to come to international level. 
MustHave is: (http://musthave.ua)

a) Ideal combined with each other things.

b) High-quality fabrics and accessories.

c) $100 \%$ author patterns.

d) More than 1000 models available.

e) Family looks for mothers and children.

f) Limited tailoring is taking care of your personality.

4. Nenka (http://nenka.ua/) is young brand based in second largest city after capital, Kharkiv. Brand

"Nenka" is comparably young brand, they work with retail production, but all their sales based online. Founded by Kateryna Kuznecova in 2012 this brand is created by passionate youth who is dreaming to expand trends of Ukrainian national symbols among citizens and abroad. Currently the brand has 50 employees and targets the middle segment of the Ukrainian consumer. Distinctive feature of the brand are ethnic motifs and affordable, low cost of qualitative products. For now, brand position its' marketing and management solution just on Ukrainian market: Website presented just on Russian and Ukrainian and as a delivering method you can choose just system, which is based in Ukraine either collect your purchasing in Kharkiv store. Although, brand is becoming popular in the country and due to its low cost, costumers prefer brand to many other competitors. Inventors themselves claim, that brand is real proof that Ukrainian high-quality products can and must be affordable. They said that first aim of brand creation was promoting of national heritage and national symbols, and second - show to Ukrainian youth that can and should stop their choice on locally produced garment.

\section{Constraints Faced by Local communities/SME`s}

As noted by Pissarides (1998), SMEs are the most dynamic firms and they are the most likely to take any available niche where a comparative advantage exists, however constrained they are by economic, institutional and legal factors. These obstacles vary from one that are linked to production, like limited access to capital and credits, to those that shape the overall business environment, like excessive regulation, weak contract enforcement, inadequate infrastructure, etc. Previous research Okpara \& Mengistie (2007) shows that only $30 \%$ of the promoters were holding Diploma or higher qualification. 92\% of the SMEs are sole proprietorship business and less than 10\% could speak English language. Only 23\% promoters had better marketing skill, an essential skill for success of an enterprise. 55\% promoters felt access to finance \& marketing as bottleneck \& problem for their success. $77 \%$ of the enterprises are managed by self or family.

The interviews were talking separately with each community by researchers in their native city. As the initial condition was proposed to speak freely about problems which communities face, while more attention was devoted to their concerns about opening international market.

Additionally, we have observed current business models and marketing approaches, analyzed environment, supply chain and brand identity. Moreover, we have analyzed past, present and future prospect of business to get full picture of analyzing communities. Comparing results, we concluded that communities face similar problems and have similar concerns regarding opening international market. Therefore, we have merged analyzed data in following list which can be equally corresponded to all four communities. 


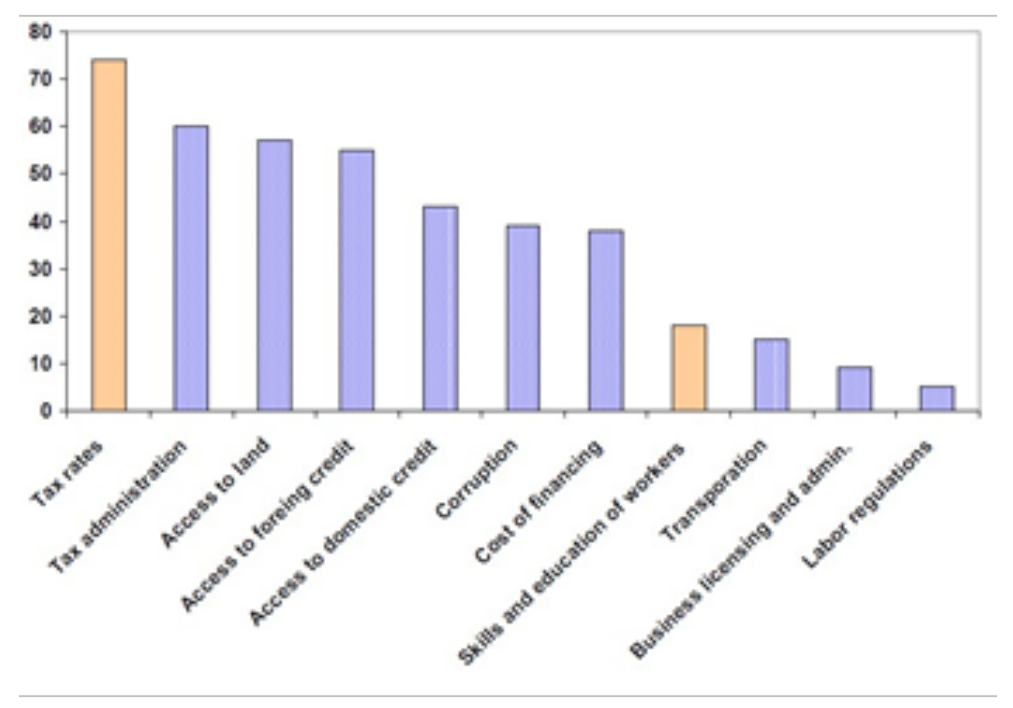

Figure 1: Most cited constraints to SMEs, Source: World Bank (2007a)

The constraints as faced by communities as researched in both the countries are listed below:

a) Lack of better technology for increasing quality and variety of products.

b) The products have no branding which could probably create a future market or awareness.

c) Lack of strong supply chain to quickly connect big cities as well as rural areas.

d) External stereotypes about products' quality and price.

e) The accounts on Social Networks are not visible enough.

f) The concepts of online selling through e-marketplaces such as Amazon or eBay are not thought off.

g) Consistency and quality in the final products not always correspond to expectances.

h) Word of mouth as a tool for marketing was missing in many of the cases, where in we realized that the brand or artists where not known to the consumer due to low quantities.

i) Small or medium size of production office, what is resulted in difficulties to increase sales.

j) Defined and strong management strategy is lacked in all off cases.

k) Large competitors such as strong western monopolies, or cheap Asian goods.

\section{Research Methodology and Theoretical Basics}

As the theoretical base secondary data was analyzed (documents, production and marketing statistics). Following research methods was implemented: 1) Interviews: two Ethiopian and two Ukrainian communities was polled using informal approach where respondents were asked to speak freely about problems and concerns which appear regarding work on international market. 2) Non-participant observation: using retrospective approach, were analyzed environment and external irritants of analyzed questions. In addition, local business model and orientation of communities in past, present and prospects were considered. 3) Model exploration: according to particular topic and contemporary scenario were analyzed existing marketing approaches; were taking into consideration focus on developing economies and market segment detached to analyzed communities.

\section{Research Questions}

According to research aim, following questions were outlined:

a) Analyze current marketing \& management strategy of two local communities in Ethiopia and two local communities in Ukraine. 
b) Define existing problems of communities via collecting primary data.

c) Identify and propose improved marketing \& management strategy according to current business models of communities and brand aim.

d) Propose consultation and provide design solution for further expansion on international level.

\section{Result and Discussions}

Beyene (2002), among the measures needed to support SME developments are:

a) Undertake a thorough review of the policy and regulatory environment with the aim of determining their weaknesses and learning from best practices within and outside Africa and revamp their laws, regulations and procedures in a manner that will stimulate the growth of MSEs.

b) Regularly review policies to determine their effectiveness.

c) Continued effort to harmonize laws, regulations and procedures at national and regional levels.

As can be seen from data above, communities face different scope of problems, including technological and quality issues. Although, it is evident that huge part of concerns consists of marketing and management mistakes or imperfectness, what can play dramatic role in success of brand campaign. Therefore, our research has raising actuality and may result in significant positive impact for all of communities.

Regardless differentiation in business models and marketing approaches, we found problems which are faced by communities very common. Additionally, considering fact that countries have similar level of economy development and the main target of expanding market to the international level is the same, we have merged solution part in one general set of recommendations which have just some slight particularities regarding differentiation in consumer expectations and experiences in cultural aspect.

The analysis of brands in Ukraine and Ethiopia was done. As a result, was realized that there is an intense need for the brands to strategize their business in order to face the competition built by foreign mass market brands entering these developing economies. Today the world of fashion is changing, with numerous high-street multinational retailers such as Zara, Gap and H\&M, the power of trends and fashion has shifted, as well as the accessibility of fashion. Now, we also observe that there is scope for local brands to establish themselves against foreign brands as they are less accessible to the consumer as they are expensive for the masses. One of the recent cases of success story of brands in developing countries (India) is Zara. It entered the Indian market four years ago, and today holds a major market share in metropolitan cities of India and has forced the local brands to shift into other small cities of the country. On the contrary Chinese brands, have been very strong in the domestic market for practically all consumer goods which is also a very strong example for marketing and promotion to consumer.

To product most effective techniques of marketing we devised a market strategy for these brands to stay in competition. The main reason of the poor performance of the small business entrepreneurs is mainly due to lack of managerial competence and experience (Bhatia \& Batra, 2003). The company must have a clear strategy which is in line with the marketing mix to reach the selected segment group (Kotler, 2008). Following are the components in our opinion that are required to develop a sustainable strategy for the fashion communities we studied. 


\section{Market Penetration Through Brand Extensions}

In the last decade, we observed that the fashion and textile sector transformed into fashion and lifestyle products which opens a great way to product extensions under the same brand name. Smith and Aaker (1992) defined brand extension as "the use of an established brand name to enter new product categories or classes". This strategy consists in using a current brand name to launch a product in a category considered as new for the company. This new product has different functions and a different nature in comparison with the product the brand used to do. As an example, the MAFI, an Ethiopian brand recently launched a line is shoes which has Ethiopian hand-woven designs. Regarding Ukraine brand "Nenka", recently they have proposed line of accessories in national style which are compliment clothes from regular collections as well as exude as independent segment. During the research, we suggested the communities to make a wider range of products under the same brand name which involve lesser investment and more consumer involvement.

Certain advantages of brand extension are- faster growth (Albrecht et al., 2013), development of product assortment (Kapferer and Tabatoni, 2013), lower introduction costs (Tauber, 1988; Keller, 2003), increased consumer acceptance (Tauber, 1988), market share (Smith and Aaker, 1992; Lucas et al., 1994), sales and profit (Spekman et al., 1998), brand image (Aaker, 1991; Balanchander and Ghose,2003), brand awareness (Stankeviciute and Hoffmann, 2010) and customer loyalty.

In order to implement brand extension successfully we would suggest implementing Keller's Customer-Based Brand Equity (CBBE) model for further strengthening of the company. According to the model, building a strong brand involves four steps: 1) Establishing proper brand identity that is, establishing proper breadth and depth of brand awareness. 2) Creating the appropriate brand meaning through strong, favorable and unique brand associations. 3) Eliciting positive, accessible brand responses. 4) Forging brand relationships with customers that are characterized by intense, active loyalty.

Hence one of the measures to occupy market segments through a robust brand model inclusive of brand extensions and hold share of the market against foreign brands.

\section{Product Differentiation}

A differentiation strategy must be based on two key factors: the strategic customers, the company has to identify their needs and what they will value, and also on the key competitors, to be different, the company has to identify against who it is competing (Hitt et al., 2016). Differentiation strategies exist in order to bring the companies competitive advantage. In order to understand why they should differentiate themselves, it is important to understand what competitive advantages the companies are offering to the consumers. If we take examples of both countries we studied, were discovered that the cheap Chinese product have occupied the market which are low quality products. We do not deny the fact that Chinese products are perfectly placed in price margins but still there exist a variety of people which would like to pay a premium price for domestic products.

The differentiation is due to buyers perceiving experience or product which they expect for, therefore, the particularities do not have to be very big, and differentiation can just be made by a unique packaging, advertising campaign, sales promotion or distribution chain.

The accentuation can also be made by the product itself; the main sources of differentiation for products are: 
a) Differences in the product's functional aspects

b) Differences in quality

c) Differences in price (Hoyle, 2000).

Hence in order to compete with the local market and the existing market leaders these communities need to essentially innovate in their product so that the consumer recognizes the potential and is ready to pay a premium price for it.

\section{Social Entrepreneurship and Image Identity}

A company's image can be described as the overall perception of the company. The image can be enhanced by promotional activities, environmental factors, competitor's actions or by nonpaid for activities, such as word of mouth. Image is formed as a result of all the experiences, values and the impression that external actors have about the company. The companies from Ethiopia and Ukraine are a living example of sustainable development, conscious consumption and sustainable material sourcing. Such factors could be used to build up brand image in the understanding of local and foreign consumers. These brands should take shape in terms of social entrepreneurship models. These new kinds of companies are defined as "integrated enterprises" or "hybrid enterprises", and they can generate different forms of social innovation. Hybrid enterprises are those enterprises "straddling the boundary between the profit business world and the social mission-driven public and not for profit organizations. Thus, they do not fit completely in either sphere" (Hockerts, 2006). Designing sustainable and strong brands with a message has been of great significance on the commercial market. A strong brand is the company's most powerful asset and the importance of it is recognized by various companies (Melin, 1999). An effective image does three things for a products or company; it establishes the product's planned character, it differentiates the product from competing products and it delivers emotional power (Kotler \& Keller, 2011). Such a message of social hybrid enterprises shall attract a lot of consumer to buy products. To highlight here the case of Awra Amba community in Ethiopia, the existence of such a community is a live example of such social development and such stories work quite well in the consumer market. There is a small margin of people supporting such communities but surely is ever increasing.

\section{Pricing Strategy}

Local fashion communities are generally small or medium enterprises in size and are able to produce and sell very limited quantities of products which are often a threat to their growth as a business. Here concepts of mass production or economies of scale shall not fair very well as the core market strategy of social cause shall not succeed. Since the products belong the niche market segment these communities could always opt for a premium price segment but not very high thought. When many firms are competing for the same consumer with homogeneous product offerings, price defines the competitive position, and is as a powerful competitive weapon (Kotler \& Dubois, 2003; Lucas et al., 1994). According to Shankar and Bolton, (2004) the following list summarizes considerations and factors for determination of pricing strategies:

a) Market factors - market and city characteristics (metropolitan, small city).

b) Chain factors -chain size, positioning, in regard to corporate mission and polices.

c) Store factors - store size, category assortment.

d) Category factors - size assortment, storability, extent of necessity.

e) Brand factors - brand equity or preference, relative brand advertising, relative trade deals. 
f) Customer factors - consumer sensitivity to prices changes.

\section{E-Retailing and Social Media}

E -retailing and social media found a natural fit with fashion and lifestyle merchandise. Selling online is directly connected to exhibiting online through various means of social media. Ethiopia is still very nascent in approach to social media and online selling as internet is still more expensive then water in the country whereas we found that Ukraine is quite in the social media mode. The brands from Ukraine are present on the internet and are also practicing online selling but do not achieve much success in this type of selling. The emergence of social media (e.g., Facebook, Instagram) has boosted interest in word of mouth and viral marketing among brands. Word of mouth (WOM) - interpersonal communication about products and services between consumers is one of the most influential sources of marketplace information for consumers (Arndt, 1967; Alreck \& Settle, 1995). When WOM travels on the Internet, it is much faster and effective in terms of communication and convincing the consumer to buy a particular product as it's accepted by a particular target group. The companies we consulted need to essentially form a very strong social media standing and essentially promoting the social message what they are working for to sell beyond borders. The tools and approaches for communicating with customers have changed greatly with the emergence of social media; therefore, businesses must learn how to use social media in a way that is consistent with their business plan (Mangold and Faulds 2009).

\section{Supply Chain Capabilities}

As markets go global and competitions turning intense, organizations are fast realizing the immense potential of a proactive Supply Chain Management (SCM) to improving their market positions in this cut-throat business environment. The tangible benefits of SCM implementation include shortening the product development life cycle, increasing on-time order delivery, reducing production costs, improving quality, reducing inventory, and bettering inventory management. (Alam, 1996). It has been pointed out that understanding and practicing (SCM) has become an essential prerequisite to staying in the competitive global race and to growing profitably (Power et al., 2001; Moberg et al., 2002). Many studies found that supply chain could be used by SMEs with considerable success. Spekman et al., (1998) and Quayle, (2003) found that the introduction of supply chain has helped in reducing costs without compromising on customer satisfaction levels. Many studies found that supply chain could be used by SMEs with considerable success. The perceived and realized benefits of SCM system consists of tangible and intangible benefits. During the research it was observed that not only the SME's have limited access to selling channels but also the final production is very less in quantity due to less financial capacity and sometimes availability of raw materials. A good supply chain channelization shall help the raw materials to reach the production sites and further on go ahead to the markets.

\section{Intellectual Property}

In the 90's a very famous indigenous art of Banaras weaving in India began to get copied by the Chinese but was not paid much attention by the Indian government. By the beginning of the millennium the artists began to suffer so bad that they had to close their mills resulting into the death of state of art Banaras weaving. Fashion communities mostly came into the marketplace due to small but very effective innovation which leads to sustainable development in their societies and hence they have survived till today. In order to take their product beyond borders they essentially need to register it under intellectual property rights 
laws in the countries they were originated from. We understand the fact that fashion products couldn't successfully come under IPR laws but registering would surely protect rights of the workers in such communities and also go much ahead in saving their product from getting replicated and mass produced by production economies. During our research, we found brilliant examples of traditional Ukrainian embroideries and handlooms of Ethiopia for woven fabric which could suffer major duplication in the coming future if not protected. Hence, we suggest that registering the state-of-the-art procedures under Geographical indication (GI) would be a very important measure to save such art and make sustainable business for the communities. World Trade Organization's Trade Related Intellectual Property Rights (TRIPS) Agreement, adopted in 1994, Geographical Indications (GIs) are "indications which identify a good as originating in the territory [of a member] where a given quality, reputation or other characteristic of the good are essentially attributable to its geographical origin".

Highlighted clusters were proposed to analyzed communities as the main elements of successful business expansion. We cannot take personal responsibility for positive growth of analyzed communities, as linked above marketing and management solutions were proposed to brands as suggestions and researchers cannot guaranty their full and coherent implementation. Lastly as agreed by many authors in academic literature SMEs business success were classified into the following categories: (1) entrepreneur characteristics, (2) characteristics of $\mathrm{SME},(3)$ management and knowhow (4) products and services (5) customers and markets, (6) the way of doing business and cooperation, (7) resources and finance (8) strategy, (9) external environment, and (10) internet.

\section{Conclusions and Further Scope of Research}

In this research, we tried to come as close as to analyze and seek solutions for the problem of local communities of both the countries. There is a need of systematic management to be implied in these communities in order to face the competition in the garment and textile sector. The opening of trade policies in the countries have raised a serious threat as the consumer today is essentially price sensitive and when has more options in a lower price range is automatically attracted. However, we also see the novelty of product and the social message in selling on such brand to the consumer which is an important feature in the consumer markets. Further in this research we would suggest to research about communities worldwide and come up with government organizations to support their interests and consult them of marketing and production areas in developing countries.

\section{References}

Aaker, D. A. (1991). Managing Brand Equity: Capitalizing on the Value of a Brand Name. New York.

Alam, A. (1996). Supply chain management. Journal of Strategic Management, 13, 80-86.

Albrecht, C. M., Backhaus, C., Gurzki, H., \& Woisetschläger, D. M. (2013). Drivers of brand extension success: What really matters for luxury brands. Psychology and Marketing, 30(8). https://doi.org/10.1002/mar.20635

Alreck, P. L., \& Settle, R. B. (1995). The importance of word-of-mouth communications to service buyers. Proceedings of American Marketing Association.

Arndt, J. (1967). Role of Product-Related Conversations in the Diffusion of a New Product. Journal of Marketing Research, 4(3). https://doi.org/10.1177/002224376700400308 
Balachander, S., \& Ghose, S. (2003). Reciprocal spillover effects: A strategic benefit of brand extensions. Journal of Marketing, 67(1), 4-13.

Beyene, A. (2002). Enhancing the competitiveness and productivity of small and medium scale enterprises (SMEs) in Africa: An analysis of differential roles of national governments through improved support services. Africa Development: A Quarterly Journal of CODESRIA, 27(3-4), 130-156.

Bhatia, B. S., \& Batra, G. S. (2003). Entrepreneurship and Small Business Management. Deep and Deep Publications PVT. Ltd.

Carrier, C. (1994). Intrapreneurship in large firms and SMEs: A comparative study. International Small Business Journal, 12(3), 54-61.

Central Intelligence Agency. (2016). The World Factbook 2007. Government Printing Office. https://www.cia.gov/library/publications/the-world-factbook/geos/up.html

Cohen, L., Manion, L., \& Morrison, K. (2000). Research Methods in Education: Routledge Taylor \& Francis Group.

Curran, J., \& Blackburn, R. (2000). Researching the small enterprise. Sage.

Dubois, J. (2008). Roots and Flowerings of Ethiopia's Traditional Crafts. UNESCO. unesdoc. unesco.org/images/0018/001846/184662eo.pdf

Eisenhardt, K. M., \& Graebner, M. E. (2007). Theory building from cases: Opportunities and challenges. Academy of Management Journal, 50(1), 25-32.

Fifield, P. (2012). Marketing strategy. Routledge.

Gebrehiwot, A. (2006). Business Development Services (BDS) In Ethiopia: Status, Prospects, and Challenges in the Micro and Small Enterprise Sector. Awassa, Ethiopia.

Ghobadian, A., \& Gallear, D. N. (1996). Total quality management in SMEs. Omega, 24(1), 83-106.

Greenan, K., Humphreys, P., \& Mclvor, R. (1997). The green initiative: Improving quality and competitiveness for European SMEs. European Business Review.

Haile Michael, M. (2006). Awramba: A community resolute to self-help. Mamo Haile Michael', Ethiopia's premier news and views website [online]. www.ethiomedia.com/carepress/ haile_michael_mamo_awramba.html

Hallberg, K. (2000). A market-oriented strategy for small and medium scale enterprises (Vol. 63). World Bank Publications.

Hitt, M. A., Ireland, R. D., \& Hoskisson, R. E. (2016). Strategic management: Concepts and cases: Competitiveness and globalization. Cengage Learning.

Hockerts, K. (2006). Entrepreneurial opportunity in social purpose business ventures. In Social entrepreneurship. Palgrave Macmillan, London.

Hoyle, D. (2000). Automotive quality systems handbook. Elsevier.

ICS. (2001). Small Entreprenership in Ukraine: The Process of Development.

Kapferer, J.-N., \& Tabatoni, O. (2012). The LVMH-Bulgari agreement: Changes in the luxury 
market that lead family companies to sell up. Journal of Brand Strategy, 1(4), 389-402.

Keller, K. L. (2003). Brand synthesis: The multidimensionality of brand knowledge. Journal of consumer research, 29(4), 595-600.

Keller, K. L., Parameswaran, M., \& Jacob, I. (2011). Strategic brand management: Building, measuring, and managing brand equity. Pearson Education India.

Khanna, T., \& Yafeh, Y. (2007). Business groups in emerging markets: Paragons or parasites? Journal of Economic Literature, 45(2), 331-372.

Koter, P., \& Keller, K. (2011). A framework for marketing management.

Kotler, P., Armstrong, G., Saunders, J., \& Wong, V. (2008). Principles of marketing (5th ed.). : Financial Times/ Prentice Hall.

Kotler, P., \& Dubois, B. (2003). Marketing management (11th ed.). Prentice-Hall.

Lucas, G. H., Bush, R. P., Gresham, L. G., \& Griendling, R. (1994). Retailing. Houghton Mifflin Company.

Mangold, W. G., \& Faulds, D. J. (2009). Social media: The new hybrid element of the promotion mix. Business Horizons, 52(4), 357-365.

Melin, F. (1999), Varumärkesstrategi, Liber AB, Malmö.

Moberg, C. R., Cutler, B. D., Gross, A., \& Speh, T. W. (2002). Identifying antecedents of information exchange within supply chains. International Journal of Physical Distribution \& Logistics Management.

National Bank of Ethiopia. (2011). Annual Report 2010-2011.

OECD. (2010). SMEs, Entrepreneurship, and Innovation.

Okpara, F., \& Mengistie, A. (2007). Entrepreneurship with special reference to the status of small business entrepreneurship: A case study of gondar, Ethiopia. African Research Review, 1(2), 17-42.

Okpara, J. O. (2011). Factors constraining the growth and survival of SMEs in Nigeria: Implications for poverty alleviation. Management Research Review.

Parkin, M., \& Parkin, R. (1996). The impact of TQM in UK SMEs. Industrial Management \& Data Systems.

Pissarides, F. (1999). Is lack of funds the main obstacle to growth? EBRD's experience with small-and medium-sized businesses in Central and Eastern Europe. Journal of Business Venturing, 14(5-6), 519-539.

Power, D. J., Sohal, A. S., \& Rahman, S. U. (2001). Critical success factors in agile supply chain management-An empirical study. International journal of physical distribution \& logistics management.

Quayle, M. (2003). A study of supply chain management practice in UK industrial SMEs. Supply Chain Management: An International Journal.

Reinecke, G., \& White, S. (2004). Policies for Small Enterprises: Creating the right environment for good jobs. International Labour Organization. 
Rose, R. C., Kumar, N., \& Yen, L. L. (2006). The Dynamics of Entrepreneurs'success Factors in Influencing Venture Growth. Journal of Asia Entrepreneurship and Sustainability, 2(2), 133.

Sapovadia, V. K. (2015). Analyzing Challenges \& Opportunities of Ethiopian SMEs: Micro \& Macro Economic Drivers. Available at SSRN 2589674.

Schiffman, L. G., \& Kanuk, L. (1992). Consumer Behavior. Prentice-Hall of India.

Schoenbachler, D. D., \& Gordon, G. L. (2002). Multi-channel shopping: Understanding what drives channel choice. Journal of Consumer Marketing.

Shankar, V., \& Bolton, R. N. (2004). An empirical analysis of determinants of retailer pricing strategy. Marketing Science, 23(1), 28-49.

Smith, D. C., \& Aaker, D. A. (1992). Managing Brand Equity: Capitalizing on the Value of a Brand Name. Journal of Marketing, 56(2). https://doi.org/10.2307/1252048

Spekman, R. E., Kamauff, J. W., \& Myhr, N. (1998). An empirical investigation into supply chain management: A perspective on partnerships. Supply Chain Management: An International Journal.

Stankeviciute, R., \& Hoffmann, J. (2011). The slippery slope of expansion-Look to the luxury sector to understand how brand extensions affect parent brands. Marketing Management, 20(4), 26.

Stokes, D., \& Lomax, W. (2008). Marketing: A brief introduction. Thomson.

Storey, D. J. (2016). Understanding the small business sector. Routledge.

Tauber, E. M. (1988). Brand leverage: Strategy for growth in a cost-control world. 28(4), 26-31.

Tetteh, E., \& Burn, J. (2001). Global strategies for SMe-business: Applying the SMALL framework. Logistics Information Management.

Tsepko, О. (2010). Export marketing survey: Ukrainian apparel market. Режим Доступу: Ukrexport: Http://Www. Ukrexport. Gov. Ua/i/Imgsupload/File/Ukrainian_Apparel_Market_ Survey_en, 282, 29.

van der Pols, D. (2015). Business opportunity report Ethiopia textile \& apparel industry Commissioned by Netherlands Embassy in Addis Abeba CBI and Nash international BV. 